\title{
Article \\ Evaluating the Effectiveness of a Conservation Project on Two Threatened Birds: Applying Expert-Based Threat Analysis and Threat Reduction Assessment in a Mediterranean Wetland
}

\author{
Pietro Giovacchini ${ }^{1}$, Corrado Battisti ${ }^{2, *(D)}$ and Letizia Marsili ${ }^{1}$ (D) \\ 1 Earth and Environmental Sciences Department, Università degli Studi di Siena-Physical, Via P.A. Mattioli 4, \\ 53100 Siena, Italy; p.giovacchini1@student.unisi.it (P.G.); letizia.marsili@unisi.it (L.M.) \\ 2 Torre Flavia' LTER (Long Term Ecological Research) Station, Protected Areas-Regional Park Service, \\ Città Metropolitana di Roma Capitale, Viale G. Ribotta 41, 00144 Rome, Italy \\ * Correspondence: c.battisti@cittametropolitanaroma.it
}

check for updates

Citation: Giovacchini, P.; Battisti, C.; Marsili, L. Evaluating the Effectiveness of a Conservation Project on Two Threatened Birds: Applying Expert-Based Threat Analysis and Threat Reduction Assessment in a Mediterranean Wetland. Diversity 2022, 14, 94. https://doi.org/10.3390/d14020094

Academic Editor: Luc Legal

Received: 28 December 2021

Accepted: 26 January 2022

Published: 28 January 2022

Publisher's Note: MDPI stays neutral with regard to jurisdictional claims in published maps and institutional affiliations.

Copyright: (c) 2022 by the authors. Licensee MDPI, Basel, Switzerland. This article is an open access article distributed under the terms and conditions of the Creative Commons Attribution (CC BY) license (https:// creativecommons.org/licenses/by/ $4.0 /)$.

\begin{abstract}
We applied two recent approaches largely used in biological conservation: Threat Analysis (TAN) and Threat Reduction Assessments (TRAs), assessing the effectiveness of a project focused on two water-related bird species (common tern, Sterna hirundo and little tern, Sternula albifrons), commonly breeding in some wetlands of Italy. We used the IUCN standardized lexicon for the classification of threats, utilizing a panel of experts to assess a set of regime attributes (extent, severity and magnitude) of each human-induced disturbance. Our aims were: (i) through the TAN approach, to carry out an arrangement and quantification of the main threats acting on our focal species and select the priority ones; (ii) through the TRA approach, to test the effectiveness of an operational project focused on mitigating the threats and improving the breeding success of species (i.e., building rafts and floating islands to encourage their nesting). Using the TAN approach, experts identified the following human-induced threats (IUCN code): 6.1-Generic disturbance; 7.2-Water stress; 7.3-Salinization; 8.8-Vagrant dogs; 8.8-Mediterranean gulls; 8.8-Wild boars, all significantly different in their magnitude. Among them, wild boars and Mediterranean gulls appeared the priority threats with the greatest extent, intensity and magnitude. Using the TRA approach, after the project, we assessed an overall decrease in the threat magnitude of $23.08 \%$ ( $21.42 \%$ when considering only the threats directly affected by our project). These data suggest that further efforts should be devoted to achieving greater effectiveness of conservation actions focused on our target species. With limited time and resources to quantify threats, expert-based approaches could be useful for rapidly assessing the effectiveness of small conservation projects by providing a range of scores obtained following an analytical procedure. In this regard, Threat Analysis and Threat Reduction Assessment could be considered useful tools to support adaptive management in project management cycles.
\end{abstract}

Keywords: Threat Analysis; TRA index; Sterna hirundo; Sternula albifrons; magnitude; adaptive management; effectiveness

\section{Introduction}

When launching conservation projects focused on target species in demographic decline, it is necessary to monitor the effectiveness of the actions aimed at reducing the causes of anthropogenic threats. This can be useful for providing information to correctly achieve the objectives with regards to adaptive management [1].

Project monitoring is a strategy to obtain data about the results and effectiveness (i.e., the success) of our conservation actions focused on targets and threats. In this regard, many technical approaches and tools are available, which aim to monitor the status of the target species of conservation concern. In this regard, it has been highlighted that project monitoring should not only identify biological targets but also indicate the level of success. Indeed, it has recently emerged that monitoring through biological indicators 
(see [2]) based on the quantification of the status of the biodiversity targets shows some weaknesses: for example, the biological components often show long response times and are observable on different spatial scales due to their ecological, phenological, and behavioral characteristics. This can make it difficult to evaluate the effectiveness of projects using biological indicators [3]. To overcome this problem, alternative approaches have recently been developed that also focus on assessing the threat events impacting our targets, recording the changes in their regime and considering specific attributes (e.g., extent, intensity, magnitude; [4]). In this regard and following a DPSIR framework (Driving forces-Pressure-State-Impact-Response; [5]), the focus shifted from the status indicator (demographic status of the species) to the pressure indicators (threat events). Having limited time and resources, an assessment of this type can be carried out quickly by a project team using expert-based approaches [6].

Recently, Salafsky et al. [7] introduced the "Threat Analysis" (hereafter, TAN). Through this approach, it is possible to assign a nomenclature (and a standard code) to any threat event, quantifying it using expert-based scores, in order to build a conceptual framework in which the causal relationships between conservation targets, direct and indirect threats and driving forces are explicit with cause-effect chains. The quantification of the regime of each threat allows obtaining a ranking among them to identify the priority ones that require immediate action in a pragmatic and operational way [8]. In this sense, it will be possible to define objectives addressed for the priority threats (i.e., with the highest rank) acting on the selected targets [9]. Through a quick procedure, it will be possible to assign scores to each regime attribute (e.g., extent, intensity, magnitude) by panels of experts, thus obtaining relative ranks and allowing a comparison between different threats among them. Furthermore, the quantification of threats allows obtaining sets of regime attributes that can be compared before and after the conservation actions, therefore evaluating the project effectiveness $[10,11]$.

The Threat Reduction Assessment (hereafter, TRA; [12]) is a further useful tool for monitoring the project's effectiveness. This approach is based on a procedure aimed to obtain indicators that make it possible to verify the level of threat reduction once the conservation actions have been carried out. This procedure has been successfully tested in operational contexts and allows obtaining an index that summarizes the effectiveness of the project (in percentage scores) in reducing the magnitude of priority threats on the targets (examples in [13-16]).

In this paper, we carried out a TAN approach on two selected water-related birds of conservation concern breeding in a Mediterranean wetland (common tern, Sterna hirundo and little tern, Sternula albifrons), selected as focal targets. This analysis provides us scores in regime attributes that are useful for identifying a set of priority threats. This first assessment allows defining an operational project that aims to reduce its magnitude, considering it a proxy of threat impact on the targets [7]. After this analysis, we performed a TRA procedure to assess the level of threat reduction induced by the conservation project, using a percentage score. Due to the difficulty of obtaining analytical data about the threat regime, we used an expert-based technique. Although the TAN approach has been applied in other Mediterranean contexts (e.g., $[10,11,17])$, to our knowledge, this is the first application of both these two approaches (i.e., TAN and TRA) in an operational project carried out in a Mediterranean wetland.

\section{Materials and Methods}

\subsection{Study Area}

The "Diaccia Botrona" wetland $\left[42^{\circ} 47^{\prime} \mathrm{N}-10^{\circ} 55^{\prime} \mathrm{E}\right]$, located in the municipalities of Grosseto and Castiglione della Pescaia (Grosseto, Tuscany, central Italy), is a coastal wetland area of about 800 ha in size area (Special Area of Conservation SAC and Special Protection Areas SPA) "Padule di Diaccia Botrona", code IT51A0011 and Ramsar Convention), located within a Regional Reserve. This area is managed by the Tuscany Region Public Agency. The marsh preserves one of the most important coastal lagoons in Tuscany with 327 floristic 
of conservation concern and phyto-geographic interest as, for example: Ranunculus trilobus Desf., Salicornia dolichostachya Moss., Mantisalca salmantica (L.) Briq. et Cavillier and Juncus subulatus Forskål [18,19].

Frequent floods in the innermost areas involve the deposition of terrigenous materials and historically affirm this geographical context with the formation of coastal dunes and back-dunes (Lake Prile). Anthropogenic changes in the wetland have taken place in historical times since the Roman Age and, more recently, with the land reclamation in the 19th and 20th Centuries with the triggering of a salinization process due to ingression of saltwater with high tides. The current division into two large patches (Diaccia and Botrona) sees for the Botrona the isolation from the remaining wetland and from the nearby watercourses with a strong stress on ecological components $[20,21]$.

Birds are an important component in the Diaccia Botrona Reserve [22,23]. Considering only the wet habitats in the area, 45 species breed, while the entire SAC-SPA includes 22 of high conservation concern (Annex I of Directive 147/2009/EC) (e.g., pied avocet Recurvirostra avosetta, black-winged stilt Himantopus himantopus, Kentish plover Charadrius alexandrinus, and others).

Among these species, we selected two focal targets (common tern, Sterna hirundo and little tern, Sternula albifrons), following a conservation criterion: these species showed a localized distribution and a declining abundance at the regional level in recent decades [24,25]. Regarding terns, Tuscany host populations separated from their respective Italian ranges, with reports of breeding for the first time in this period of the year in 1998 from the nearby Orbetello Lagoon [26,27]. Moreover, a criterion linked to the effectiveness of field sampling (these are of medium size species, easily detectable, in particular regarding the nesting sites) also allows obtaining reliable and representative data.

Since these two terns show a comparable nesting ecology [28], we considered both as a single conservation unit.

\subsection{The Logic of Project Cycle}

The staff managing the Diaccia Botrona Reserve have had to face a series of local human-induced threats. Therefore, in view of the IUCN conservation project cycle [29], it was decided to form a working group made up of a panel of experts in order to: (i) analyze the context by identifying and quantifying the local threats and ranking them to select the priority ones; (ii) define actions to mitigate the priority threats in order to favor two selected target species breeding in the wetland; (iii) once the project has been completed, monitor its effectiveness by adopting the TRA as an assessment approach.

\subsection{Identification of Stakeholders}

To identify the experts qualified for both the TAN and TRA procedures, we selected 10 operators and researchers belonging to members of a local non-profit organization $(n=4)$, personnel belonging to the Departments in charge of national strategies for protected areas $(n=4)$ and private consultants involved in protected area management $(n=2)$ (see list in the Acknowledgments). We selected the project management team as the most appropriate people to apply both the TAN and TRA procedures because they had adequate recent and historical knowledge on (i) the wetland site, (ii) the selected targets and (iii) the local threats. Moreover, they have all been involved in a conservation project, so they possess the knowledge useful for assessing the management progresses, following the logic of adaptive management [30].

This panel of experts carried out both the TAN procedure (threat naming, magnitude assessment, ranking in priorities) and the TRA procedure (percentage scores in effectiveness).

\subsection{Threat Analysis}

After identifying the two focal water-related bird species (common tern and little tern) as targets in this case study (Diaccia Botrona nature reserve), the panel of experts 
identified the local threats acting on them. In this regard, they defined "threats" using the meaning reported in [6], i.e., "as any human-related process that negatively affect specific components of biodiversity (species richness, habitat condition and area, ecosystem functioning) in a 'real world' context".

To name these threats, experts used the IUCN unified classification of direct threats [7], assigning a standardized taxonomic code to any anthropogenic threat (review in [9]).

After this step, we asked the experts the following questions: (i) what are the threats acting on common tern and little tern in the Diaccia Botrona reserve? (ii) Once classified (sensu IUCN; see [7]), which of these threats can be reduced (i.e., mitigated in their impacts on targets) with a project? For each direct threat, the panel of experts assigned a score to two regime attributes (extent and severity) using a scale from 1 (low) to 4 (high). "Extent" can be measured as the proportion in the species habitat that has been, is or will be affected by the threat when compared to the total surface available (all the suitable areas of habitat for the two focal species; [31]). "Severity" constitutes past, present or future pressure levels that are estimated to be caused by the threat event and may affect the target (for example, by altering its composition, structure, vitality and integrity), leading to an impact on our targets, i.e., to a potential or real specific alteration (see [32]). Finally, for each threat, the two scores (extent and severity) have been summed, obtaining a score for the total magnitude-a compound variable. "Magnitude" represents the capacity of a threat to exert a general pressure (and a consequent impact) on the selected targets [7].

When the experts assigned a score for the extent and severity and after we obtained the values of magnitude, we calculated the averaged values (and standard deviation) for each attribute (extent, severity and magnitude) of each threat. Finally, the experts ranked the threats when regarding the magnitude values, obtaining a list of threat magnitudes in decreasing order. The threats showing the highest values in mean magnitude represented the priority threats.

Experts based their judgement both on local expertise and on the available local ("grey") literature [22,33,34].

\subsection{Conservation Actions}

To mitigate the human-induced threats, in 2010, a project focused on the two focal species (common tern and little tern) was started. This project envisaged the construction of rafts and islets in only the Diaccia area, as well as some interventions to regulate the water levels, to favor the reproduction of the two target species and mitigate the effects of threats. There is evidence indicating the isolation of the nest structures from terrestrial predators and human disturbance can favor these species [35-37]. Floating rafts $(1.5 \times 1 \mathrm{~m}$ to $2 \times 2 \mathrm{~m}$ and $1.5 \times 2 \mathrm{~m}$ in size; $n=8)$ and islets $(6 \times 6 \mathrm{~m}$ in size; $n=7)$ were built until 2020 .

\subsection{Threat Reduction Assessment}

After the TAN, and when the project has been closed, we carried out a TRA procedure [12-14]. First, experts were contacted, requesting them to choose a suitable assessment period. After, we conducted the open-ended interviews ( $n=10$ experts) in October 2021.

We asked the experts the following questions: (i) regarding the local threats obtained from the TAN procedure, what score (from $1=$ low to $4=$ high) would you assign to the attributes of the area (i.e., the portion of habitats in the site that the threat affects), intensity (i.e., the effect, or severity, of the threat) and urgency (i.e., the immediacy of addressing actions against the threats), keeping the effects on the two selected targets (i.e., common tern, Sterna hirundo and little tern, Sternula albifrons) in mind?; and (ii) how much you consider the reduction in each threat following the realization of the project (assessing a percentage score, from 0 to 100)? (Details in $[6,14]$ ).

After each step, the collected data were statistically processed to obtain the averaged values (and standard deviation) of each threat regarding area, intensity, urgency and percentage in reduction after the project. 
The average values were used to rank the threats according to their relative importance (from 1 the lowest to 6 the highest). A total threat score was computed after all the threats were ranked. Finally, we added the value of the mean percentage reduction for each threat.

After the ranking and scoring exercises, the total ranking scores for each threat were multiplied by the percentage of the threat met to yield a raw score for that threat. The Threat Reduction Index (TRA-I) value was derived by dividing the sum of the raw scores for each threat by the total possible rankings of all the threats and multiplying by 100, i.e., TRA-I = total raw scores $/$ total rankings $\times 100$ (details in [12]). Thus, the TRA-I value indicates the response to all the combined threats to the overall conservation project over the assessment period. All calculations were conducted automatically with Microsoft Excel software.

\subsection{Statistical Analyses}

We compared the averaged values performing the Kruskal-Wallis test for equal medians using the PAST 1.89 software [38]. Alpha level was set to 0.05.

\section{Results}

\subsection{Threat Analysis}

Regarding the TAN procedure, the panel of experts identified the following humaninduced direct threats and named them following the international IUCN nomenclature:

- 6.1-Recreational activities in the surrounding area too (in particular, un-managed recreational fruition by birdwatchers, hunters and fishermen with consequent disturbance on breeding birds);

- 7.2-Water management/use (in particular: water stress due to alteration of the hydrographic regime following land reclamation and water collection and pumping for agricultural uses in surrounding croplands and others), a threat largely occurring in several wetlands of central Italy [39];

- 7.3-Other ecosystem modifications (in particular, water salinization due to saline ingression from the sea; see [40]);

- 8.8-Problematic species, more in particular: wild boars (Sus scrofa), a native mammal largely restocked in Tuscany from historical times; Mediterranean gulls (Larus michahellis), a generalist native birds, recently spreading from coastal sites to anthropized inland areas and vagrant dogs (Canis familiaris). For their different characteristics and regimes, we considered each of these three threats independently.

The values of the threat regime attributes showed as wild boars and Mediterranean gulls appeared to be the threats with the largest extent, intensity and magnitude (Table 1; Figure 1), with a significant difference in magnitude among threats $(\mathrm{H}=17.37, p=0.003$; Kruskall-Wallis test for equal medians).

Table 1. Threat Analysis (TAN) procedure. Mean values (and \pm standard deviation) in regime attributes (area, intensity and magnitude) for the six human-induced direct threats selected in the Diaccia Botrona wetland.

\begin{tabular}{cccc}
\hline Threats & Area & Intensity & Magnitude \\
\hline 7.2-Water stress & $2.7( \pm 0.82)$ & $2.7(0.95)$ & $5.4( \pm 1.71)$ \\
8.8-Wild boars & $3.6( \pm 0.70)$ & $2.8(0.92)$ & $6.4( \pm 1.17)$ \\
8.8-Mediterranean gulls & $3.6( \pm 0.70)$ & $3.3(0.67)$ & $6.9( \pm 1.10)$ \\
8.8-Vagrant dogs & $1.9( \pm 0.88)$ & $2.1(0.99)$ & $4( \pm 1.82)$ \\
6.1-Generic disturbance & $2.7( \pm 1.16)$ & $1.8(0.63)$ & $4.6( \pm 1.65)$ \\
7.3-Salinization & $2.7( \pm 1.06)$ & $2.4(1.26)$ & $5( \pm 2.26)$ \\
\hline
\end{tabular}




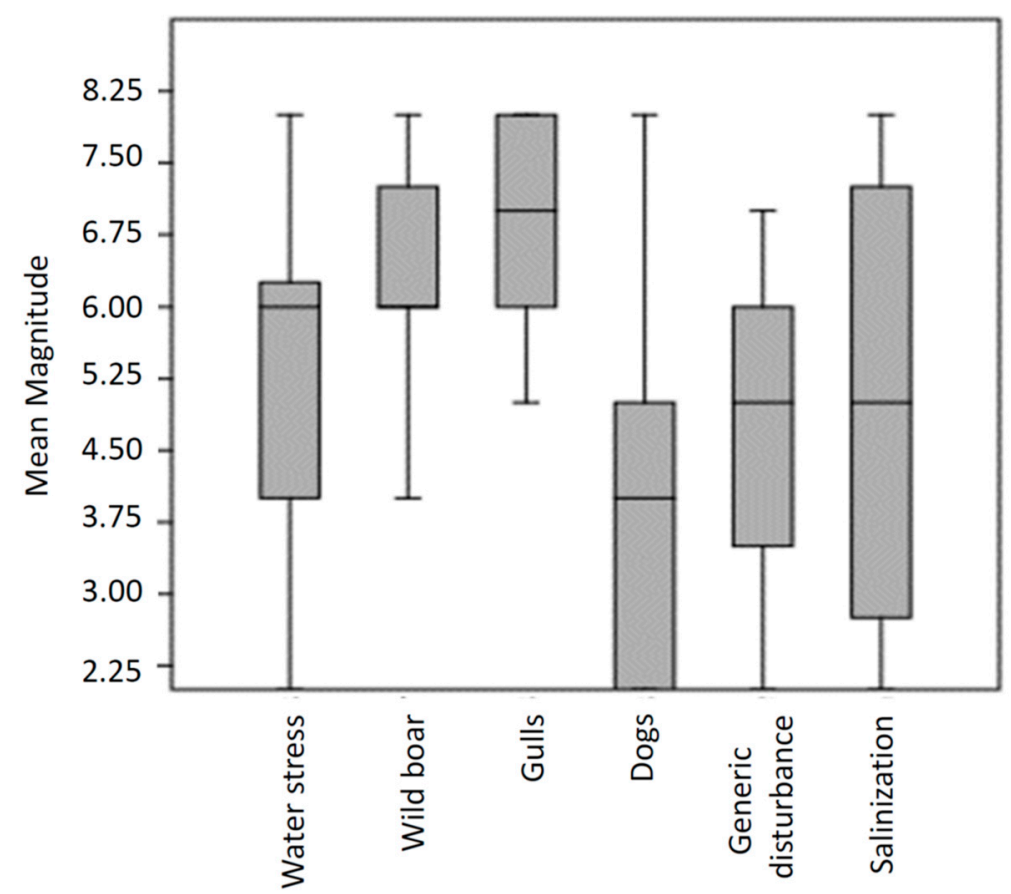

Figure 1. Box plots for magnitude values of the six human-induced direct threats selected by the panel of experts in the Diaccia Botrona wetland.

\subsection{Conservation Actions}

The islets were ignored by both common tern and little tern because, perhaps, they were more exposed to the risk of being surrounded by vast dry clayey banks, easily accessible by terrestrial predators. Moreover, in some parts of the Diaccia Botrona reserve, their realization was conditioned by the limited accessibility of the operating machines where water is present in the breeding season.

The rafts were regularly occupied for a total of three pairs of common tern (excluding 2013, 2014, 2017, 2018 without nesting: 2010 and 2011: 2 nesting pairs; 2012: 1; 2015: 3; 2016: 2; 2017: 1; 2019 and 2020: 1). Subsequent new installations in other areas did not help in observing the expected increase in their use. Tern populations in the Diaccia Botrona wetland show a discontinuous but increasing trend over the years, with a maximum valuation of 21 pairs for common tern in 2021 and 19 pairs for little tern in 2019.

\subsection{Threat Reduction Assessment}

After the projects, the panel of experts carried out the TRA procedure, assessing the area, severity and urgency of each threat and obtaining the mean values (and standard deviation) for each attribute (Table 2). Attributes have been ranked and summed: wild boars and Mediterranean gulls showed the highest total rank ( $\geq 15$; Table 2). Finally, the experts assessed the percentage in threat reduction following the project. The highest percentage score $(\geq 20)$ has been observed for water stress, wild boars and vagrant dogs. The procedure showed a total TRA-I $=23.08 \%$ considering all the threats affecting the breeding of the target birds. However, considering only the three main threats directly involved by the project score in effectiveness was $21.42 \%$ (Table 3 ). 
Table 2. Threat Reduction Assessment (TRA) procedure. Regime attributes of area, intensity and urgency and related ranks for the Threat Reduction Assessment and procedure to calculate the TRA-I index. (1): sum of ranking of area, intensity and urgency. (2): estimated percentage of threat mitigation over the assessment period. TRA-I index $=\Sigma$ (raw score $/$ total ranking) $\times 100=23.08 \%$.

\begin{tabular}{|c|c|c|c|c|c|c|}
\hline Threats & Area & Rank & Intensity & Rank & Urgency & Rank \\
\hline 7.2-Water stress & $2.7( \pm 0.82)$ & 2 & $2.7( \pm 0.95)$ & 4 & $3.5( \pm 0.53)$ & 6 \\
\hline 8.8-Wild boars & $3.6( \pm 0.70)$ & 6 & $2.8( \pm 0.92)$ & 5 & $3.3( \pm 0.82)$ & 5 \\
\hline $\begin{array}{c}\text { 8.8-Mediterranean gulls } \\
\text { (predation by) }\end{array}$ & $3.6( \pm 0.70)$ & 6 & $3.3( \pm 0.67)$ & 6 & $2.9( \pm 0.99)$ & 3 \\
\hline $\begin{array}{l}\text { 8.8 - Vagrant dogs } \\
\text { (predation by) }\end{array}$ & $1.9( \pm 0.88)$ & 1 & $2.1( \pm 0.99)$ & 2 & $1.4( \pm 0.70)$ & 1 \\
\hline 6.1-Generic disturbance & $2.7( \pm 1.16)$ & 2 & $1.8( \pm 0.63)$ & 1 & $1.8( \pm 0.79)$ & 2 \\
\hline 7.3-Salinization & $2.7( \pm 1.06)$ & 2 & $2.4( \pm 1.26)$ & 3 & $2.9( \pm 0.99)$ & 3 \\
\hline \multirow{2}{*}{ Threats } & \multicolumn{3}{|c|}{ criteria ranking } & \multirow{2}{*}{ total ranking ${ }^{1}$} & \multirow{2}{*}{ Percent threat reduced ${ }^{2}$} & \multirow{2}{*}{ Raw score } \\
\hline & Area & Intensity & Urgency & & & \\
\hline 7.2-Water stress & 2 & 4 & 6 & 12 & 32 & 3.84 \\
\hline \multirow{2}{*}{$\begin{array}{l}\text { 8.8-Wild boars } \\
\text { 8.8-Mediterranean gulls } \\
\text { (predation by) }\end{array}$} & 6 & 5 & 5 & 16 & 27 & 4.32 \\
\hline & 6 & 6 & 3 & 15 & 16 & 2.4 \\
\hline $\begin{array}{l}\text { 8.8-Vagrant dogs } \\
\text { (predation by) }\end{array}$ & 1 & 2 & 1 & 4 & 21 & 0.84 \\
\hline 6.1-Generic disturbance & 2 & 1 & 2 & 5 & 17 & 0.85 \\
\hline \multirow[t]{2}{*}{ 7.3-Salinization } & 2 & 3 & 3 & 8 & 20 & 1.6 \\
\hline & & & & 60 & & 13.85 \\
\hline
\end{tabular}

Table 3. Attributes of area, intensity and urgency and related ranks for the Threat Reduction Assessment (TRA) and procedure to calculate the TRA-I index, considering only the three threats directly involved in the project. (1): sum of ranking of area, intensity and urgency. (2): estimated percentage of threat mitigation over the assessment period. TRA-I index $=\Sigma($ raw score $/$ total ranking $) \times 100=21.42 \%$.

\begin{tabular}{|c|c|c|c|c|c|c|}
\hline Threats & Area & Rank & Intensity & Rank & Urgency & Rank \\
\hline \multirow{2}{*}{$\begin{array}{l}\text { 8.8-Wild boars } \\
\text { 8.8- Mediterranean gulls } \\
\text { (predation by) }\end{array}$} & $3.6( \pm 0.70)$ & 3 & $2.8( \pm 0.92)$ & 2 & $3.3( \pm 0.82)$ & 3 \\
\hline & $3.6( \pm 0.70)$ & 3 & $3.3( \pm 0.67)$ & 3 & $2.9( \pm 0.99)$ & 2 \\
\hline $\begin{array}{l}\text { 8.8-Vagrant dogs } \\
\text { (predation by) }\end{array}$ & $1.9( \pm 0.88)$ & 1 & $2.1( \pm 0.99)$ & 1 & $1.4( \pm 0.70)$ & 1 \\
\hline \multirow{2}{*}{ Threats } & \multicolumn{3}{|c|}{ criteria ranking } & total ranking 1 & Percent threat reduced 2 & Raw score \\
\hline & Area & Intensity & Urgency & & & \\
\hline \multirow{4}{*}{$\begin{array}{l}\text { 8.8-Wild boars } \\
\text { 8.8- Mediterranean gulls } \\
\text { (predation by) } \\
\text { 8.8-Vagrant dogs } \\
\text { (predation by) }\end{array}$} & 3 & 2 & 3 & 8 & 27 & 2.16 \\
\hline & 3 & 3 & 2 & 8 & 16 & 1.28 \\
\hline & 1 & 1 & 1 & 3 & 21 & 0.63 \\
\hline & & & & 19 & & 4.07 \\
\hline
\end{tabular}

\section{Discussion}

The Diaccia Botrona wetland is a biodiversity hot spot, particularly for bird species and communities. Similar to many other Mediterranean wetlands, these ecosystems are embedded in anthropized landscapes (see [41]) where, since historical times, a series of human-induced driving forces acted, modifying the environmental matrix: in the last two centuries, land reclamation has transformed these wetlands into agricultural areas, and, in recent decades, urbanization and infrastructures (and consequent habitat fragmentation) have given rise to several threats and related impacts on biodiversity, as observed also in many other Mediterranean wetlands (e.g., [9,42]).

Many of these threats can act on birds, even of high conservation interest. Through the TAN approach, a panel of experts with a specific skill and context-related background 
selected a set of main human-induced events that act locally on two local bird species, which were selected as conservation targets.

These threats are all directly or indirectly linked to the presence of humans. For example, the occurrences of vagrant dogs were due to an uncontrolled frequentation of people (e.g., birdwatchers, hunters, fishermen) or derived from escaped/abandoned farm dogs. Differently, wild boars frequent the area due to a demographic increase at a regional scale induced by continuous re-stocking of animals due to poaching activity (for Tuscany, see $[43,44])$. In this regard, there is a lot of evidence of wild boars' impact on nests of wetland-related birds $[45,46]$.

Analogously, the increase in Mediterranean gulls is indirectly linked to the landscape anthropization, as these species are increasingly linked to urban waste landfills, a recent phenomenon largely known (e.g., [47]). The water stress and the consequent process of water salinization were due to long-time saline ingression due to complex historical processes linked to land reclamation, water pumping by agriculture and lack of water management at landscape scale [48]; for this effect on birds, see [49-51]. Finally, the disturbance from uncontrolled frequentation of wetland by people may also affect the ecology and behavior of bird species, especially during the breeding period (e.g., [52]; review in [53]).

However, the ranking procedure in the TAN procedure showed that the experts considered Mediterranean gulls and wild boars the threats with the highest magnitude. In this regard, the project actions, which involved the creation of suitable substrates for nesting for the two focal species (floating rafts and artificial islands), aimed at reducing the effects of these threats, focused on these priority threat events.

Once the project was implemented, the panel of experts assessed how effective this may have been on the target species through the TRA procedure. The value obtained in percentage effectiveness (about 20\%) suggests how these actions had a weak success, both considering all the threats affecting the focal species and considering only the threats directly interested in the project. These results can be attributed to the difficulty of mitigating some of these threats and the delay in response in terms of the demographic increase and reproductive success of the two focal species, a problem largely known in conservation studies (see [54]). However, we think that the low predictive power may be also a result of a lack of information on the threat magnitude: when these data are lacking, the experts had little confidence in their predictions (or, however, divergent opinions about the relative importance of the threats).

The results obtained by monitoring using the TRA-I index make the experts aware that the project needs an adaption (for example, changing number, location and size in structures).

The use of the TRA approach made it possible to obtain a given percentage value (TRA-I) using an expert-based approach. Although expert-based procedures show weaknesses [55], they also show points of strength [56] as highlighted in the TRA tool, with many examples in conservation arenas worldwide (see [13-16,57]). For example, when the time and resources are limited or the events to monitor are complex and not analytically measurable, pragmatic and quick expert-based approaches can allow the project team to focus by orienting judgment on specific questions (see [58]). In this regard, the scores in threat regime attributes, overcoming anecdotal judgments, political considerations and nontechnical dynamics, allow addressing the project with priorities and related solutions [7]. In our case, the scores in TRA-I percentages will be useful to support decision-making along the future development process of the local project, following a logic of active adaptive management [30].

Author Contributions: Conceptualization, C.B.; investigations: P.G. and C.B.; writing-original draft preparation, C.B. and P.G.; writing — review and editing, C.B. and L.M. All authors have read and agreed to the published version of the manuscript.

Funding: This research has no funding. 


\title{
Institutional Review Board Statement: Not applicable.
}

Data Availability Statement: All the data involved in this study are available on request from the corresponding author.

\begin{abstract}
Acknowledgments: The panel of experts was composed by: Giuseppe Anselmi, Paolo Caldelli, Fabrizio Farsi, Pietro Giovacchini, Davide Grimaldi, Paolo Migliorini, Maria Cristina Paolini, Sandro Pilozzi, Fabio Sabatini and Paolo Stefanini. Some of these data were collected in collaboration with "Gruppo Ornitologico Maremmano-Studi Naturalistici A. Ademollo". The first part of this project was supported by the Provincia di Grosseto (Tuscany, Italy; Act n. 2366/2011). Two anonymous reviewers and Editors suggested useful comments that improved the first draft of the manuscript. Alex Zocchi reviewed the English style and language.
\end{abstract}

Conflicts of Interest: The Authors declare no conflict of interest.

\section{References}

1. Rist, L.; Campbell, B.M.; Frost, P. Adaptive management: Where are we now? Environ. Conserv. 2013, 40, 5-18. [CrossRef]

2. Noss, R.F. Indicators for monitoring biodiversity: A hierarchical approach. Conserv. Biol. 1990, 4, 355-364. [CrossRef]

3. Yoccoz, N.G.; Nichols, J.D.; Boulinier, T. Monitoring of biological diversity in space and time. Trends Ecol. Evol. 2001, 16, 446-453. [CrossRef]

4. Salafsky, N.; Margoluis, R.; Redford, K.H.; Robinson, J.G. Improving the practice of conservation: A conceptual framework and research agenda for conservation science. Conserv. Biol. 2002, 16, 1469-1479. [CrossRef]

5. Maxim, L.; Spangerberg, J.H.; O'Connor, M. An analysis of risks for biodiversity under the DPSIR framework. Ecol. Econ. 2009, 69, 12-13. [CrossRef]

6. Margoluis, R.; Salafsky, N. Measures of Success; Island Press: New York, NY, USA, 1998.

7. Salafsky, N.; Salzer, N.; Stattersfield, A.J.; Hilton-Taylor, C.; Neugarten, R.; Butchart, S.H.M.; Collen, B.; Cox, N.; Master, L.L.; O'Connor, S.; et al. A standard lexicon for biodiversity conservation: Unified classifications of threats and actions. Conserv. Biol. 2008, 22, 897-911. [CrossRef]

8. Salafsky, N.; Butchart, S.H.M.; Salzer, D.; Stattersfield, A.J.; Neugarten, R.; Hilton-Taylor, C.; Collen, B.; Master, L.L.; O'Connor, S.; Wilkie, D. Pragmatism and practice in classifying threats: Reply to Balmford. Conserv. Biol. 2009, 23, 488-493. [CrossRef]

9. Battisti, C.; Poeta, G.; Fanelli, G. An Introduction to Disturbance Ecology; Springer: Cham, Switzerland, 2016.

10. Battisti, C.; Luiselli, L.; Pantano, D.; Teofili, C. On threats analysis approach applied to a Mediterranean remnant wetland: Is the assessment of human-induced threats related to different level of expertise of respondents? Biodivers. Conserv. 2008, 17, 1529-1542. [CrossRef]

11. Battisti, C.; Luiselli, L.; Teofili, C. Quantifying threats in a Mediterranean wetland: Are there any changes in their evaluation during a training course? Biodivers. Conserv. 2009, 18, 3053-3060. [CrossRef]

12. Salafsky, N.; Margoluis, R. Threat reduction assessment: A practical and cost-effective approach to evaluating conservation and development projects. Conserv. Biol. 1999, 13, 830-841. [CrossRef]

13. Mugisha, A.R.; Jacobson, S.K. Threat reduction assessment of conventional and community-based conservation approaches to managing protected areas in Uganda. Environ. Conserv. 2004, 31, 233-241. [CrossRef]

14. Anthony, B.P. Use of modified threat reduction assessments to estimate success of conservation measures within and adjacent to Kruger National Park, South Africa. Conserv. Biol. 2008, 22, 1497-1505. [CrossRef] [PubMed]

15. Matar, D.A.; Anthony, B.P. Application of modified threat reduction assessments in Lebanon. Conserv. Biol. 2010, $24,1174-1181$. [CrossRef] [PubMed]

16. Lamsal, R.P.; Adhikari, B.; Khanal, S.N.; Dahal, K.R. Threat reduction assessment approach to evaluate impacts of landscape level conservation in Nepal. J. Ecol. Nat. Environ. 2015, 7, 29-37.

17. Alhirsh, I.; Battisti, C.; Schirone, B. Threat analysis for a network of sites in West Bank (Palestine): An expert -based evaluation supported by grey literature and local knowledge. J. Nat. Conserv. 2016, 31, 61-70. [CrossRef]

18. Sforzi, S.; Selvi, F. Flora vascolare della Palude "Diaccia Botrona" (Castiglione della Pescaia, Grosseto). Atti Soc. Toscana Sci. Nat. Mem. Ser. B 1999, 106, 99-114.

19. Tomei, P.E.; Guazzi, E.; Kugler, P.C. Le Zone Umide della Toscana: Indagine Sulle Componenti Floristiche e Vegetazionali; Centro Stampa della Giunta Regionale: Florence, Italy, 2001.

20. De Silva, M.; Guarducci, A.; Rombai, L. The Grosseto plain (Tuscany, Italy) in historical maps (18th-20th centuries): Georeferencing of historic landscape. E-Perimetron 2013, 8, 21-36.

21. Colombini, I.; Chelazzi, L. Evolution, Impact and Management of the Wetlands of the Grosseto Plain, Italy. In Coastal Water Bodies: Nature and Culture Conflicts in the Mediterranean; Scarpini, F., Ciampi, G., Eds.; Springer: Dordrecht, The Netherlands; Heidelberg/Berlin, Germany; London, UK; New York, NY, USA, 2010.

22. Corsi, F. Progetto di conservazione e ripristino ambientale del Padule della "Diaccia Botrona". Suppl. Ric. Biol. Selvag. 1991, 16, 309-312. 
23. Puglisi, L.; Fontanelli, A.; Baldaccini, N.E. L'avifauna della Diaccia Botrona: Stato attuale e recente evoluzione. Ric. Di Biol. Della Selvag. 1995, 95, 1-50.

24. Giovacchini, P.; Stefanini, P. Dieci anni di censimenti (2006-2015) dell'avifauna nidificante ed estivante nella ZPS “Padule di Diaccia Botrona". In Proceedings of the Abstract XVIII Convegno Italiano di Ornitologia, Caramanico Terme, Italy, 17-20 September 2015; p. 54.

25. Gustin, M.; Brambilla, M.; Celada, C. Stato di conservazione e valore di riferimento favorevole per le popolazioni di uccelli nidificanti in Italia. Riv. Ital. Ornitol. 2016, 86, 3-58. [CrossRef]

26. Brunelli, M.; Sorace, A. Avvistamenti e comportamenti insoliti. Alula 1999, 6, 179-184.

27. Brichetti, P.; Fracasso, G. Ornitologia Italiana; Alberto Perdisa Editore: Bologna, Italy, 2006; Volume 3.

28. Baaloudj, A.; Bouzid, A.; Nedjah, R.; Samraoui, F.; Samraoui, B. Distribution and breeding of the Slender-billed Gull Chroicocephalus genei, Common Tern Sterna hirundo and Little Tern Sternula albifrons in Algeria. Rev. Ecol. 2018, 73, 385-395.

29. Battisti, C. Unifying the trans-disciplinary arsenal of project management tools in a single logical framework: Further suggestion for IUCN project cycle development. J. Nat. Conserv. 2018, 41, 63-72. [CrossRef]

30. McCarthy, M.A.; Possingham, H.P. Active adaptive management for conservation. Conserv. Biol. 2007, 21, 956-963. [CrossRef] [PubMed]

31. Ervin, J. WWF Rapid Assessment and Prioritization of Protected Area Management (RAPPAM) Methodology; WWF: Gland, Switzerland, 2002.

32. TNC (The Nature Conservancy). The Five-S Framework for Site Conservation: A Practitioner's Handbook for Site Conservation Planning and Measuring Conservation Success; The Nature Conservancy: Arlington, VA, USA, 2000; Volumes I and II.

33. World Wildlife Found Italia; Washington, DC, USA. Piano di Gestione della Palude della Diaccia Botrona. Part II. Analisi Territoriale e Proposte di Gestione. Unpublished Report, 1993.

34. Ancora, S.; Bianchi, N.; Fortino, S.; Leonzio, C.; Dipartimento di Scienze Ambientali “G.Sarfatti”, Università di Siena, Siena, Italy. Indagine preliminare sulla contaminazione da piombo di origine venatoria nell'area umida "Diaccia Botrona". Unpublished report, 2010.

35. Dunlop, C.L.; Blokpoel, H.; Jarvie, S. Nesting rafts as a management tool for a declining common tern (Sterna hirundo) colony. Colon. Waterbirds 1991, 14, 116-120. [CrossRef]

36. Lampman, K.P.; Taylor, M.E.; Blokpoel, H. Caspian terns (Sterna caspia) breed successfully on a nesting raft. Colon. Waterbirds 1996, 19, 135-138. [CrossRef]

37. Coccon, F.; Borella, S.; Simeoni, N.; Malavasi, S. Floating rafts as breeding habitats for the Common tern, Sterna hirundo. Colonization patterns, abundance and reproductive success in Venice Lagoon. Riv. Ital. Ornit. 2018, 88, 23-32. [CrossRef]

38. Hammer, Ø.; Harper, D.A.T.; Ryan, P.D. PAST-palaeontological statistics, ver. 1.89. Palaeont. Electron. 2001, 4, 1-9.

39. Causarano, F.; Battisti, C. Effect of seasonal water level decrease on a sensitive bird assemblage in a Mediterranean wetland. Rend. Lincei 2009, 20, 211-218. [CrossRef]

40. Bencini, A.; Pranzini, G. The salinization of groundwaters in the Grosseto plain (Tuscany, Italy). In Study and Modelling of Saltwater Intrusion into Aquifers. Proceedings of the 12th Saltwater Intrusion Meeting, Barcelona, Spain, 1-6 November 1992; CIHS: Barcelona, Spain; CIMNE: Barcelona, Spain, 1993; pp. 161-175.

41. Perennou, C.; Beltrame, C.; Guelmami, A.; Tomàs Vives, P.; Caessteker, P. Existing areas and past changes of wetland extent in the Mediterranean region: An overview. Ecol. Mediterr. 2012, 38, 53-66. [CrossRef]

42. Rodríguez-Santalla, I.; Navarro, N. Main Threats in Mediterranean Coastal Wetlands. The Ebro Delta Case. J. Mar. Sci. Engin. 2021, 9, 1190. [CrossRef]

43. Massolo, A.; Mazzoni Della Stella, R.M. Population structure variations of wild boar Sus scrofa in central Italy. Ital. J. Zool. 2006, 73, 137-144. [CrossRef]

44. Santilli, F.; Varuzza, P. Factors affecting wild boar (Sus scrofa) abundance in southern Tuscany. Hystrix 2013, 24, 169-173.

45. Herrero, J.; Couto, S.; Rosell, C.; Arias, P. Preliminary data on the diet of wild boar living in a Mediterranean coastal wetland. Galemys 2004, 16, 115-123.

46. Baccetti, N.; Panzarin, L.; Cianchi, F.; Puglisi, L.; Basso, M.; Arcamone, E. Two New Greater Flamingo (Phoenicopterus roseus) Breeding Sites in Italy; Bulletin of the IUCN-SSC/Wetlands International Flamingo Specialist Group; Flamingo: Slimbridge, UK, 2008; Volume 16, pp. 24-27.

47. Bosch, M.; Oro, D.; Ruiz, X. Dependence of yellow-legged gulls (Larus cachinnans) on food from human activity in two western Mediterranean colonies. Avocetta 1994, 18, 135-139.

48. De Montety, V.; Radakovitch, O.; Vallet-Coulomb, C.; Blavoux, B.; Hermitte, D.; Valles, V. Origin of groundwater salinity and hydrogeochemical processes in a confined coastal aquifer: Case of the Rhône delta (Southern France). Appl. Geoch. 2008, 23, 2337-2349. [CrossRef]

49. Battisti, C.; Aglitti, C.; Sorace, A.; Trotta, M. Water level decrease and its effects on the breeding bird community in a remnant wetland in central Italy. Ekologia 2006, 25, 252-263.

50. De Zan, R.; Battisti, C.; Carpaneto, G.M. Effect of spring water stress induced by fishery farming on two duck species Anas platyrhynchos L. and Anas crecca L. in a Mediterranean wetland. Pol. J. Ecol. 2010, 58, 599-604.

51. Żmihorski, M.; Pärt, T.; Gustafson, T.; Berg, Å. Effects of water level and grassland management on alpha and beta diversity of birds in restored wetlands. J. Appl. Ecol. 2016, 53, 587-595. [CrossRef] 
52. Madsen, J. Experimental refuges for migratory waterfowl in Danish wetlands. I. Baseline assessment of the disturbance effects of recreational activities. J. Appl. Ecol. 1998, 35, 386-397. [CrossRef]

53. Steven, R.; Pickering, C.; Castley, J.G. A review of the impacts of nature based recreation on birds. J. Environ. Manag. 2011, 92, 2287-2294. [CrossRef] [PubMed]

54. Lavers, J.L.; Wilcox, C.; Donlan, C.J. Bird demographic responses to predator removal programs. Biol. Invas. 2010, 12, 3839-3859. [CrossRef]

55. Johnson, C.J.; Hurley, M.; Rapaport, E.; Pullinger, M. Using expert knowledge effectively: Lessons from species distribution models for wildlife conservation and management. In Expert Knowledge and Its Application in Landscape Ecology; Perera, A.H., Drew, C.A., Johson, C.J., Eds.; Springer: New York, NY, USA, 2012.

56. Fazey, I.; Fazey, J.A.; Salisbury, J.G.; Lindenmayer, D.B.; Dovers, S. The nature and role of experiential knowledge for environmental conservation. Environ. Conserv. 2006, 33, 1-10. [CrossRef]

57. Conteh, A.; Gavin, M.C.; McCarter, J. Assessing the impacts of war on perceived conservation capacity and threats to biodiversity. Biodivers. Conserv. 2017, 26, 983-996. [CrossRef]

58. Milatovic, L.; Anthony, B.P.; Swemmer, A. Estimating conservation effectiveness across protected areas in Limpopo Province, South Africa. Koedoe Afr. Prot. Area Conserv. Sci. 2019, 61, 1-10. [CrossRef] 